\title{
Wasteland development and the empowerment of women: The SARTHI experience
}

Madhu Sarin

Follow this and additional works at: https://knowledgecommons.popcouncil.org/departments_sbsr-pgy

Part of the Agricultural and Resource Economics Commons, Family, Life Course, and Society

Commons, Gender and Sexuality Commons, Inequality and Stratification Commons, and the International

Public Health Commons

How does access to this work benefit you? Let us know!

\section{Recommended Citation}

Sarin, Madhu. 1993. "Wasteland development and the empowerment of women: The SARTHI experience," SEEDS no. 16. New York: Population Council. 


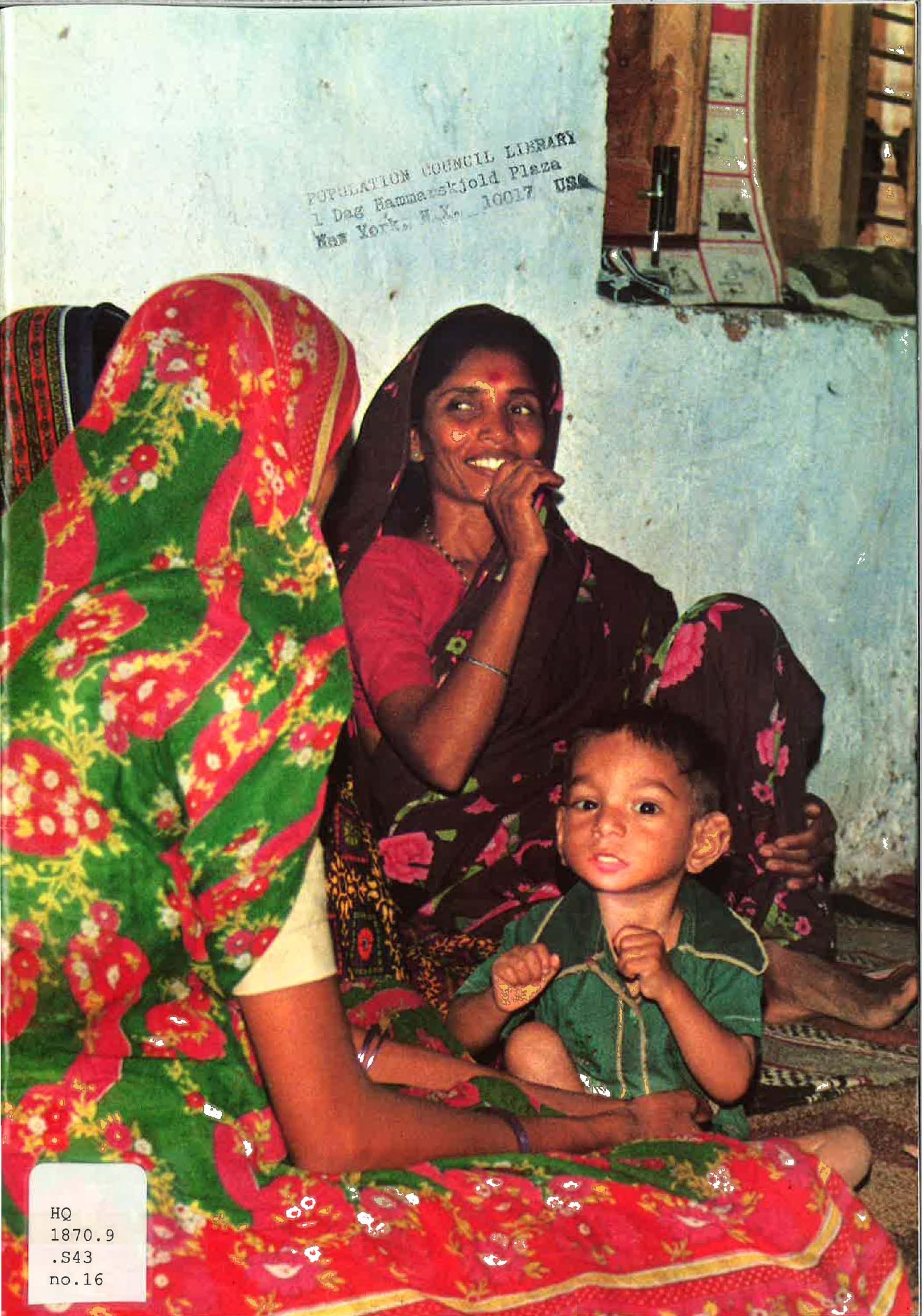


SEEDS is a pamphlet series developed to meet requests from all over the world for information about innovative and practical program ideas developed to address the economic roles and needs of low income women. The pamphlets are designed as a means to share information and spark new initiatives based on the positive experiences of projects that are working to help women generate livelihoods and to improve their economic status. The projects described in this and other issues of SEEDS have been selected because they have served not only to strengthen women's productive roles, but also to integrate women into various sectors of development, both social and economic. All projects documented in the SEEDS series involve women in decision-making, organize women locally, and address broader policy issues which affect the economic roles of women

These reports are not meant to be prescriptive, since every development effort will face somewhat different problems and possibilities. Rather, they have been written to describe the history of an idea and its implementation in the hope that the lessons learned can be useful in a variety of settings. They are also being written to bring to the attention of those in decision-making positions the vital roles that women play not only in the economies of their individual households but also in the economic life of every nation.

The author would like to dedicate this issue of SEEDS in memory of Champa Ben, a resident of Godhar Village where SARTHI's headquarters is located. Starting as a shy and apprehensive local woman who had to be coaxed into traveling to the mela at $P E D O$, just three hours away, to attend the stove building training program in 1984, Champa Ben blossomed into a wonderful and sensitive activist and trainer. She, together with her male colleague Vikram Bhai, was instrumental in getting the first women's wasteland development group formed in Muvasa. Sadly, Champa Ben died of cervical cancer at the young age of 30 in December 1989. Even through her death, however, she made local women aware of the importance of timely medical examinations to reduce the incidence of female deaths due to such diseases.

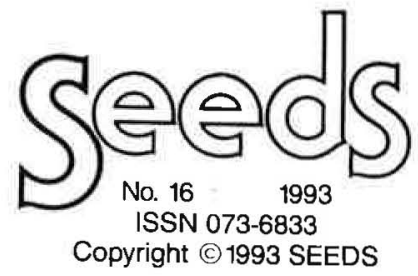

Copyright $(1993$ SEEDS
The Population Council provides project direction and administrative support for SEEDS. Editorial policy is set by the SEEDS Steering Committee: Judith Bruce (Population Council), Betsy Campbell (The Ford Foundation), Marilyn Carr (UNIFEM), Marty Chen (Harvard Institute for International Development), Margaret Clark (The Aspèn Instilute), Anne Kubisch (The Ford Foundation), Ann Leonard (The Population Council), Cecilia Lotse (UNICEF), Katharine McKee (Center for Community Self-Help), Anne Walker (International Women's Tribune Center), and Mildred Warner (Cornell University).

Publication of SEEDS is made possible by support of the Ford Foundation, The Canadian International Development Agency (CIDA), the Government of the Netherlands and the Population Council.

Statements made and views expressed in this publication are solely the responsibility of the authors and not of any organization providing support for SEEDS. 


\title{
Wasteland Development and the Empowerment of Women: The SARTHI Experience
}

\author{
by Madhu Sarin
}

\section{Introduction}

For large segments of India's rural population, rain-fed subsistence farming on small landholdings continues to be their economic mainstay. However, even in years of good rainfall, agricultural production does not meet all the needs of the household, since most families have little or no access to cash income. Agricultural production, therefore, has to be supplemented by collecting vegetative produce (referred to hereafter as "biomass"), such as firewood, fodder, small timber and medicinal roots and plants, from the surrounding natural environment.

Under the traditional gender division of labor, the gathering of biomass is generally women's work. Women thus have a much greater stake in the distribution and management of local natural resources, as they suffer the most from land degradation and deforestation. However, simply involving women in raising and planting trees, shrubs and grasses is not an adequate response, because the broader spectrum of gender relations deny women any ownership or control over land resources or the produce from these lands. Unless development projects empower women to gain greater control over the use and management of local resources, women are unlikely to benefit from land rehabilitation efforts in any lasting way.

This issue of SEEDS describes an innovative approach to rehabilitation of wastelands developed by SARTHI (Social Action for Rural and Tribal Inhabitants of India), a nongovernmental organization based in the Panchmahals District of Gujarat State in Western India. By assisting rural women to organize themselves around the rehabilitation of patches of degraded common land, SARTHI has been able to help them not only meet their needs for biomass in a more efficient and ecologically sound manner, but also to empower them to start asserting themselves in dealing with a broader range of problems. 


\section{India's Wastelands}

Of India's roughly 300 million hectares of land, some 40 million hectares are noncultivatable. Of the remaining 260 million hectares, about two-thirds are privately owned. The other third consists of what is referred to as "common" land and is under the control of government departments or local institutions. Between 30 and 50 percent of both the private and common land is estimated to be ecologically degraded to varying degrees. In India, this land is generally referred to as "wastelands"; that is, land that is not producing its potential of biomass due to ecological degradation, overexploitation or the absence of a clear management system.

It is primarily on nonprivate or "common" wastelands that the resource-poor rural population of India depends for gathering biomass. Because of growing concern over the rapid degradation of the country's land resources, the government has initiated a large program for wasteland development.

\section{The Panchmahals District}

The forests of the Panchmahals have been famous throughout Indian history. It was here that the Sultans of Ahmedabad and the Mughal emperors came on elephant hunting expeditions. Unfortunately, little of this forest land has survived under the combined pressures of illicit cutting of timber, commercial exploitation both by the princely rulers and, following independence, by the state government. Clearance for agriculture and uncontrolled grazing of domestic animals have also depleted forest land. Excessive grazing is particularly harmful as it destroys natural regeneration. Further each drought year brings a fresh onslaught as a desperate local population searches for fodder, firewood and a source of income due to the failure of local rain-fed agriculture.

The most recent droughts occurred from 1985 to 1987 , bringing acute misery to people in the region. Besides total crop failures, there was a scarcity of fodder needed to feed livestock, resulting in a heavy loss of cattle. In an area where seasonal migration for wage work is already common (as rain-fed agriculture yields only one crop per year), even larger numbers of people were forced to migrate to other areas in search of work.

Panchmahals is one of the most industrially backward districts in the Indian state of Gujarat, with 89 percent of workers still engaged in agriculture and allied activities, most making a living as small and marginal farmers. Ninety percent of the district's cultivated land is rain-fed, which leaves the area vulnerable to crop failures. Compared to Gujarat as a whole, Panchmahals has a higher population density, a far lower literacy rate (par-

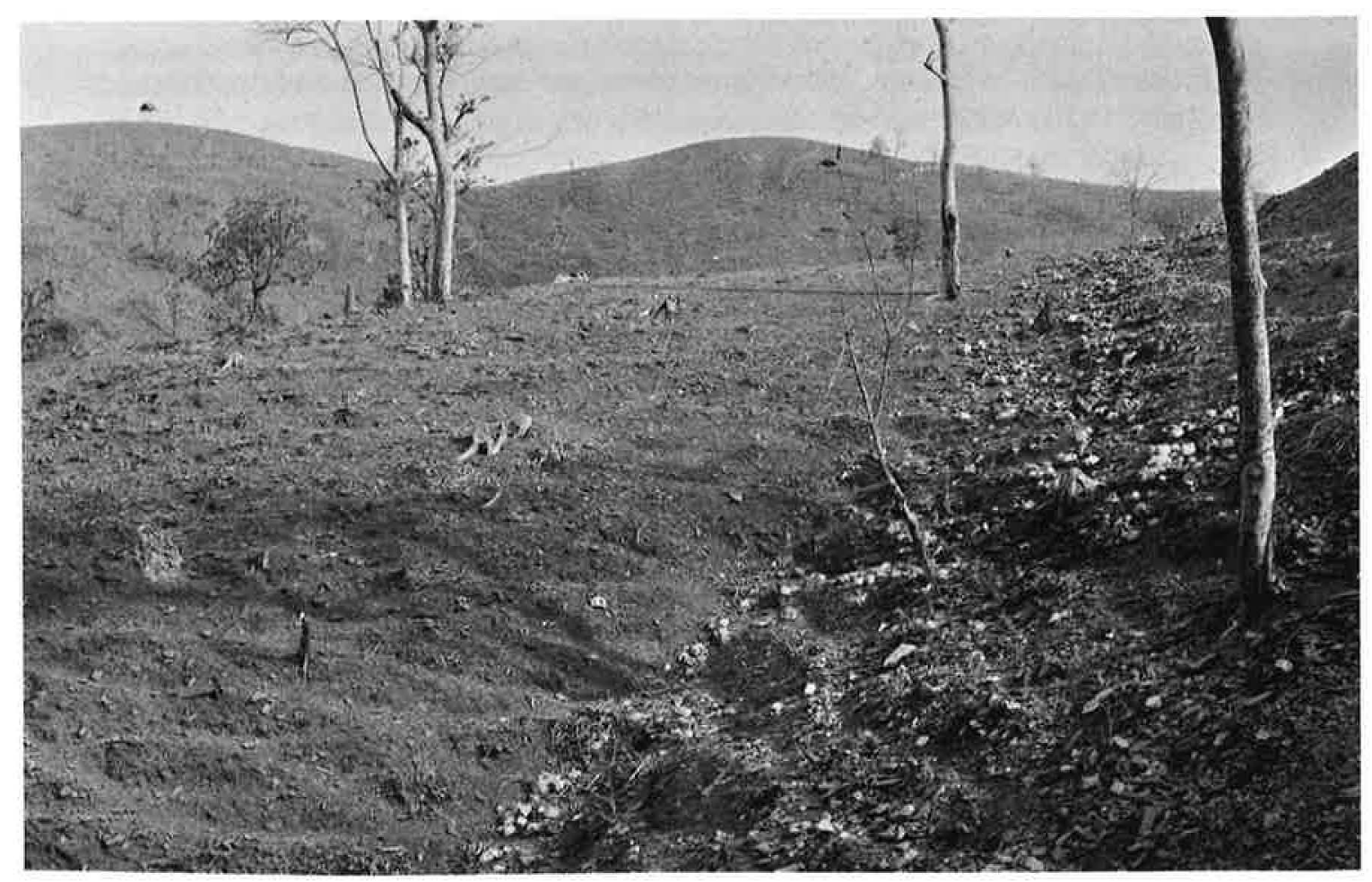


ticularly among women), less urbanization and a much higher population of Adivasis or tribal people.

Adivasis are considered to be the indigenous inhabitants of India and nationally constitute about 7 percent of the population. In Santrampur taluka (an administrative subunit of Panchmahals District), where SARTHI is working, 66 percent of the population is Adivasi as compared to only 14 percent for the state of Gujarat as a whole.

The Adivasis are essentially forest dwellers living primarily in the forest belt of central and eastern India. Among them there are a large number of different tribes, each with its distinct culture, identity and language. Although they live in areas rich in natural resources, "development" has generally passed them by.

The British introduced several measures to protect the cultural identity and economic interests of the Adivasis and, following independence, the Government of India similarly used various legislative and administrative measures to protect their interests. A "schedule" or list of recognized tribes entitles those belonging to any of the "scheduled tribes" to a range of benefits and facilities including reservation of a certain percentage of government jobs and seats in institutions of higher education, special loan and subsidy programs and so on. In areas where over 50 percent of the population belongs to scheduled tribes, special tribal area development plans are being implemented.

Legislation prevents the purchase of an Adivasi's land by non-Adivasis. However, despite all these measures, the marginalization of these tribes has increased rather than decreased. Large development projects, such as dams and power and steel plants, have displaced more Adivasis from their traditional habitats than other segments of the population. Destruction of forests through commercial exploitation and other development projects have largely destroyed the Adivasi's traditional economy-which is based on gathering and hunting in the forests-without providing them with secure, alternative livelihoods.

\section{Wasteland Management}

Throughout India, a significant proportion of land is under the control of the government. For

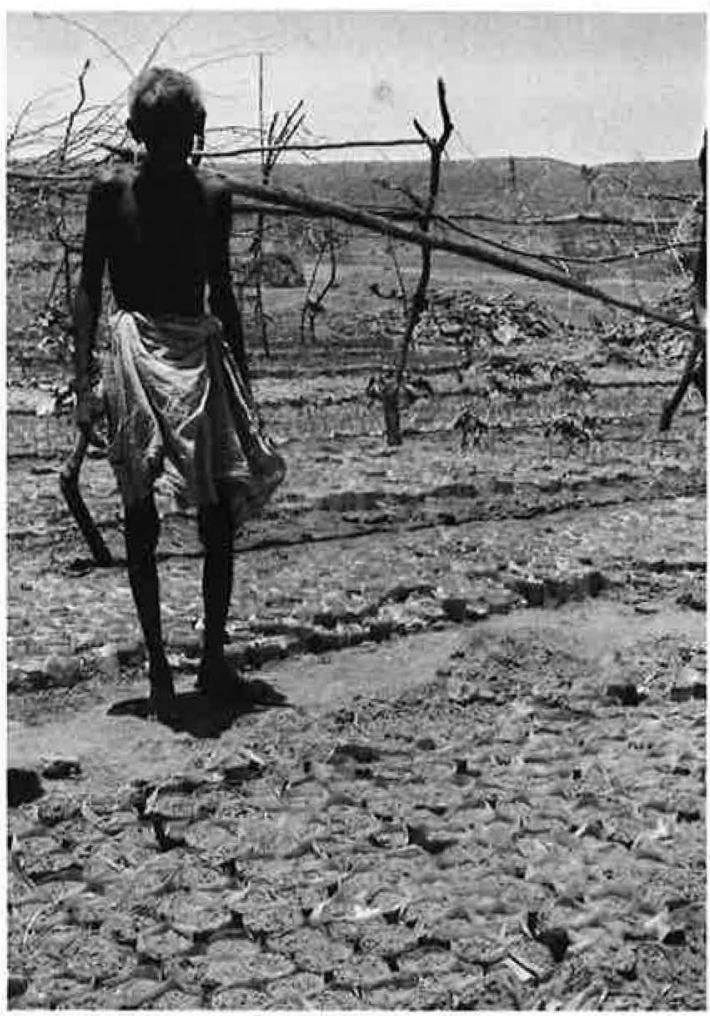

example, approximately 22 percent of the entire country's common land is controlled by state forest departments. In the area of Panchmahals where SARTHI is working, the state forest department controls 16 percent and the state revenue department another nine percent. This land is referred to as "revenue wasteland." In addition, roughly 4 percent of the country's total land is controlled by village panchayats (the smallest unit of local government covering one or more villages). This land is meant to be used primarily for common grazing. Of approximately 50,000 hectares of grazing land available in the district, at least 10,000 hectares has been encroached upon by private individuals. The rest is in a degraded and unproductive state due to the absence of any regulatory or management system.

As landholdings in the area are very small, people have always relied on supplementing agricultural production by collecting biomass from the surrounding common lands to meet many of their subsistence needs. The decline in the amount of common land available, and the continuing degradation of what remains, has made this a difficult task. As collecting subsistence biomass is traditionally women's work, the resulting hardship has fallen on women's shoulders. 


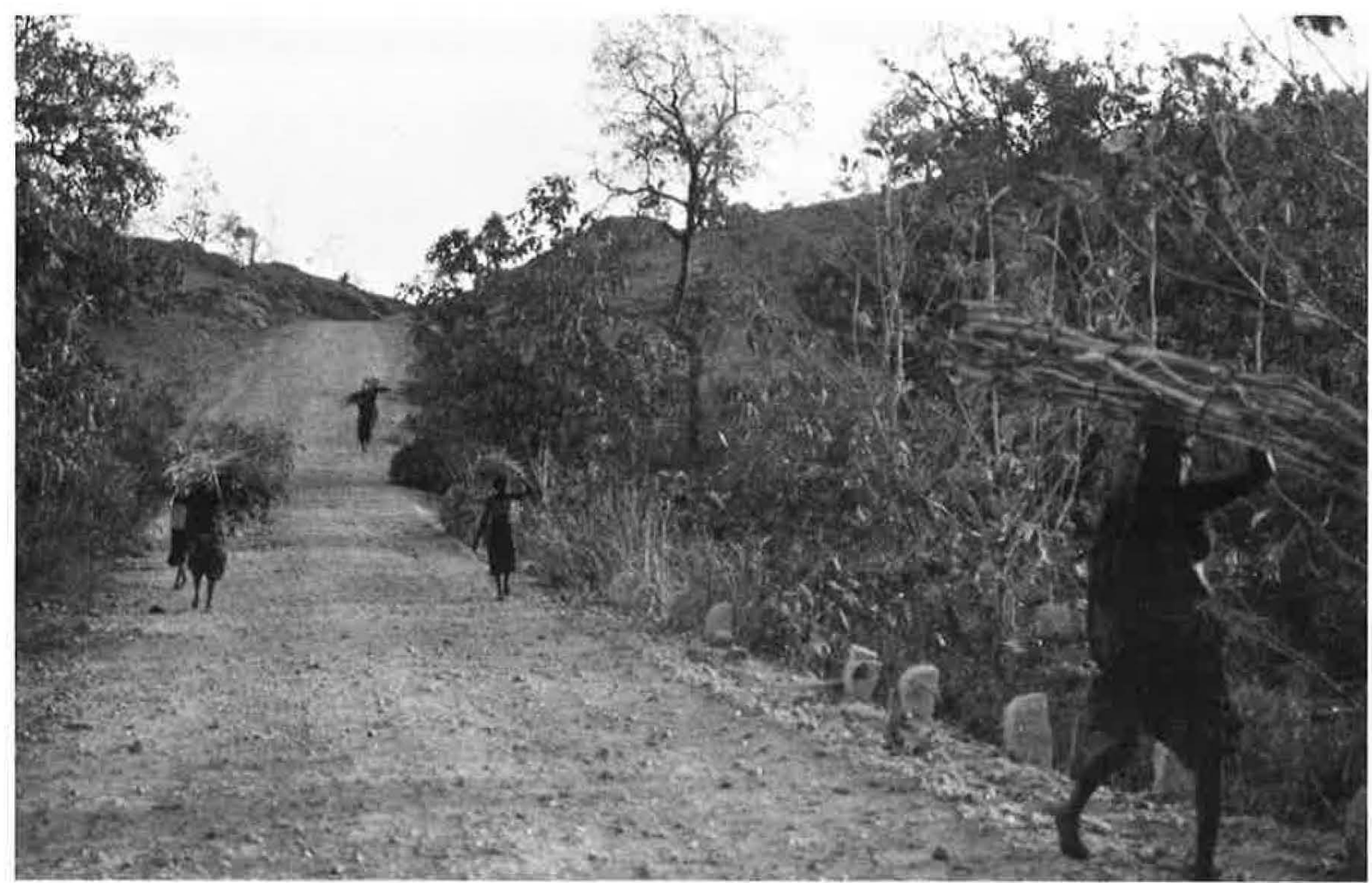

\section{Women's Status and Their Relation- ship with Natural Resources}

The status of women in Panchmahals, as in many parts of India, is low while their workload is heavy. In addition to performing housework, many women work as laborers for daily wages either in the fields of large landholders or on public works projects. Women of landowning families also perform substantial agricultural tasks. While men do the plowing and marketing of produce, women shoulder major responsibilities for hoeing, weeding, irrigating, harvesting and processing. Besides this, "women's work" includes collecting cooking fuel, fetching water and caring for livestock. This binds them to the natural resource base much more than men. It is women who have to pay the price for environmental degradation by having to walk longer distances in their daily search for fuel, fodder and water. As several women of the area have noted, "Men just expect to be served cooked food. They aren't bothered about where the firewood comes from. That is our problem!"

Due to the declining forest cover, the forest department has started enforcing restrictions on the collection of nontimber forest produce by local villagers. For instance, collecting green wood as firewood is forbidden. However, as adequate quantities of the permitted dead and dry fallen wood are no longer available, women are forced to cut green branches. If forest guards catch women cutting or carrying green wood, they either snatch the womer's sickles and axes, confiscate their headload of wood, extract a bribe or physically or orally abuse them. As forest guards are all men, the fear which most haunts the women is that of physical molestation or abuse.

Desertion, domestic violence and alcoholism (despite prohibition in Gujarat) among men, as well as husbands taking second wives to beget sons, are common problems faced by women in the area. On top of that, during drought years women often have to shoulder the burden of all the agricultural work if men migrate in search of wage employment. Some women also have to migrate with men to look for work in more prosperous areas.

Further, as is true elsewhere in India, women in Panchmahals own little land or property. Decision making concerning land use is, therefore, almost always the exclusive preserve of men. This makes rehabilitation of degraded lands by women a particularly difficult task. 


\section{Evolution of SARTHI's Women's Program}

SARTHI started working in the Santrampur area 12 twelve years ago as a branch of the Social Work and Research Centre (SWRC), an NGO based at Tilonia in the state of Rajasthan. About six years ago, it became an independent entity and adopted its current name. SARTHI's mandate is to promote integrated rural development in underdeveloped areas by improving the quality of support provided by local NGOs. Its initial work consisted of conventional development projects such as installing hand pumps, deepening wells and starting income-generating programs. Experience over the years has caused SARTHI to shift its focus to leadership development and promotion of organized action by groups of underprivileged sectors of the community, particularly women.

SARTHI's women's program evolved through initiatives undertaken with three cadres of female village workers: cook stove builders (chula mistris), women health workers and paravets (veterinary technicians).

When SARTHI began an improved cook stove program in 1983, it was the first time the organization had worked exclusively with women. Selected village women were trained as stove builders to erect improved stoves in and near their villages. By 1987, a village based cadre of thirty stove builders and four supervisors had been developed. The four supervisors became SARTHI's first full-time local female staff. As each stove builder was in touch with at least 30 to 50 other women, SARTHI found itself in contact with a large network of local women. Through regular monthly meetings of the stove builders and their supervisors, the organization developed a better understanding of the problems faced by women in the area.

In July 1988, SARTHI conducted a training program for dais (midwives, both traditional and new) in response to women's demand for access to improved health services. These Women Health Workers (WHWs) became the second cadre of trained village women. The WHW' role is to monitor women's health problems in their villages and assist those they cannot aid to get help from government services in their area.

Then in May 1990, again in response to a need articulated by local women, 10 village women were trained to work as paravets. This meant that yet another cadre of skilled local women was created. Within a span of barely two months after their training, the women paravets had managed to get almost 3,000 cattle vaccinated against foot and mouth disease.

Each of these programs provided opportunities to bring women together in a forum outside the traditional family and allowed SARTHI to learn first hand about women's problems and concerns.

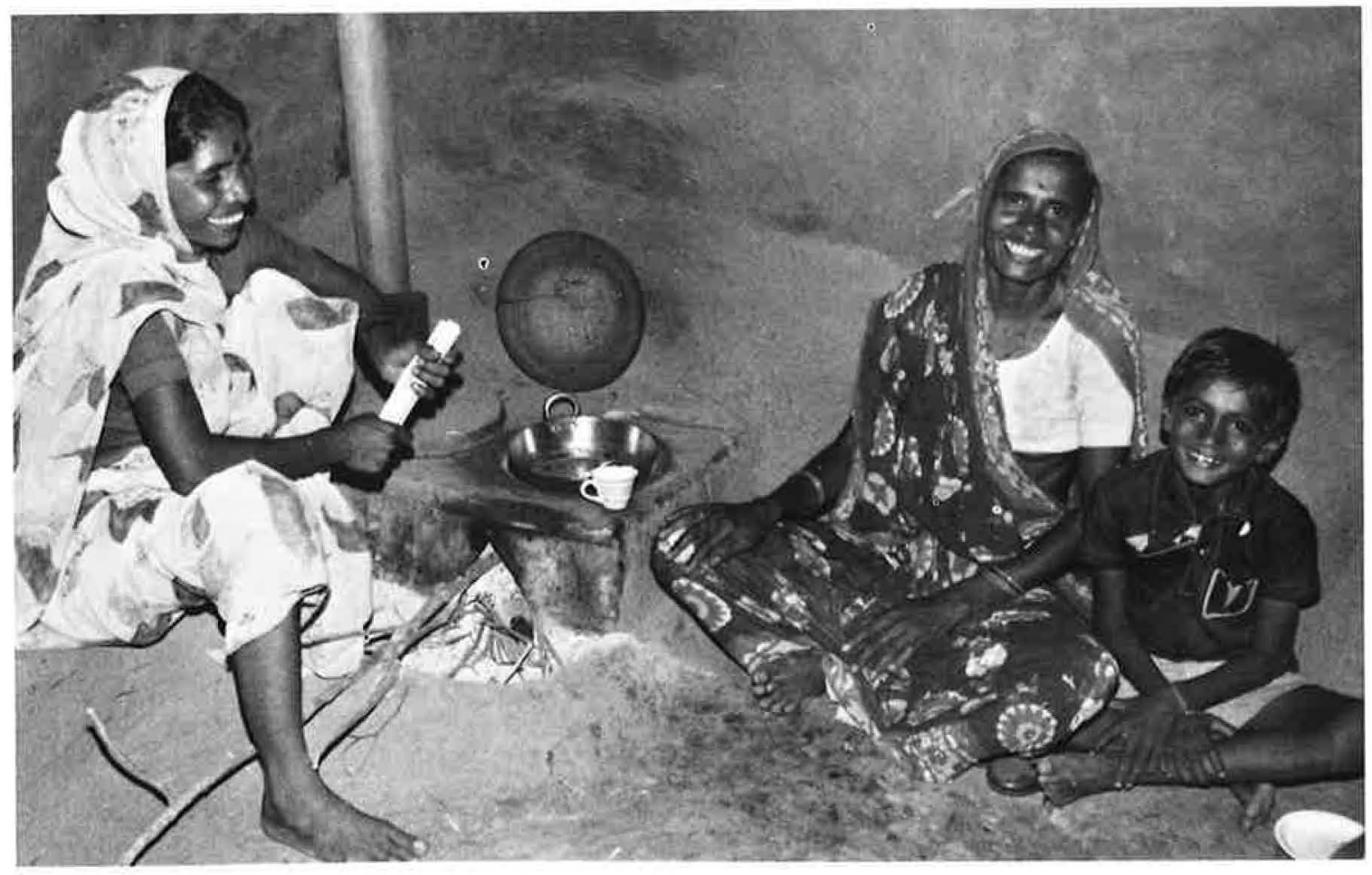


These programs also clearly demonstrated the women's capacity to organize and bring about change.

\section{Taking It One Step at a Time}

With the third successive monsoon failure in 1987, the hardship of the local people became acute. Agonizing tales of cattle dying, women's unending search for fuel, fodder, food and water, and outbreaks of various illnesses and diseases started pouring in. For the first time, SARTHI began to give serious thought to developing a more holistic approach to meeting women's needs.

in April 1987 a group of village women and SARTHI female staff were sent to PEDO', a sister NGO in Rajasthan, to attend a large women's mela (literally a fair but can refer to any large gathering of people for a specific purpose). The objective of the mela was to provide local women with an opportunity to discuss and share their problems and learn from the struggles of their sisters from other areas.

The women came back enthusiastic and excited about the possibilities of organized action. As a follow-up, in November 1987 the four women supervisors attended a training program for women staff at PEDO. Besides sharing their experiences as women, the participants discussed the possibilities of women taking collective action to solve some of their problems. For the first time, the women participated in an analysis of the environmental crisis--its causes and what women could do to reverse the trend.

The objective was to get the women to reflect on and examine the nature of environmental changes that had taken place in their area in recent years, including the causes and the impact of these changes on their daily lives. This proved to be an eye-opening exercise. The women had never looked at the totality of the problem in such a way before. For the first time, they consciously understood the significance of the trees and forests to their survival. Whether it was a decrease in soil productivity, reduced and uncertain rainfall, declining water tables, drying up of perennial

PEDO also started as a branch of SWRC and has a mandate similar to SARTHI's. It is located only three hours away by road. Due to the personal rapport between the directors of the two NGOs and their overlapping program goals, each group frequently participates in activities organized by the other. water sources, scarcity of fuel, fodder and nutritious foods or increased health problems, they could trace the causes of all of these problems back to the destruction of the forests.

Afterward, small groups of women carried out a planning exercise. They were asked to estimate the number of tress and shrubs that each member of the group required to meet her needs for firewood, fodder, construction material and other subsistence needs and to list the local tree species suitable to meet each need. The process generated tremendous interest and excitement among the women as it provided them with a concrete basis for discussing action strategies with other women.

For example, the women calculated that if cows or buffalos had to be supported entirely on tree leaf fodder, 90 large trees would be required to feed one animal each year. For a goat or sheep, 50 trees would be needed. A list of 21 local species suitable for fodder was generated. Similar calculations were made for the timber required to build a two-room house. The estimate was five to six large trees or 150 smaller ones. In addition, they estimated that 100 bamboo stalks would be needed to support a tiled roof and 200 to 300 kilograms (about 440-660 pounds) of wood would be needed for baking the tiles. The women were quite amazed at the number of trees needed to meet even their most basic needs.

Up until then, SARTHI did not have a specific program for involving women in wasteland development, but after the experience at PEDO, the women staff started discussing natural resource management issues with village women during their field visits. These experiences were then further reinforced by a 10-day training program on environmental reconstruction held at PEDO in January 1988. Eight SARTHI staff members (four of them women) participated. This event represented a qualitative shift in SARTHI's method of formulating program priorities. Instead of imposing their own predefined objectives, for the first time the staff members attempted to respond to women's priorities as articulated by women themselves.

The development of the women's wasteland groups has to be seen against the above background. At least some members of the stronger groups have participated in one or more of the camps, training sessions or visits organized by SARTHI. These experiences have been instrumental in helping women overcome their shyness or reservations about getting involved. 


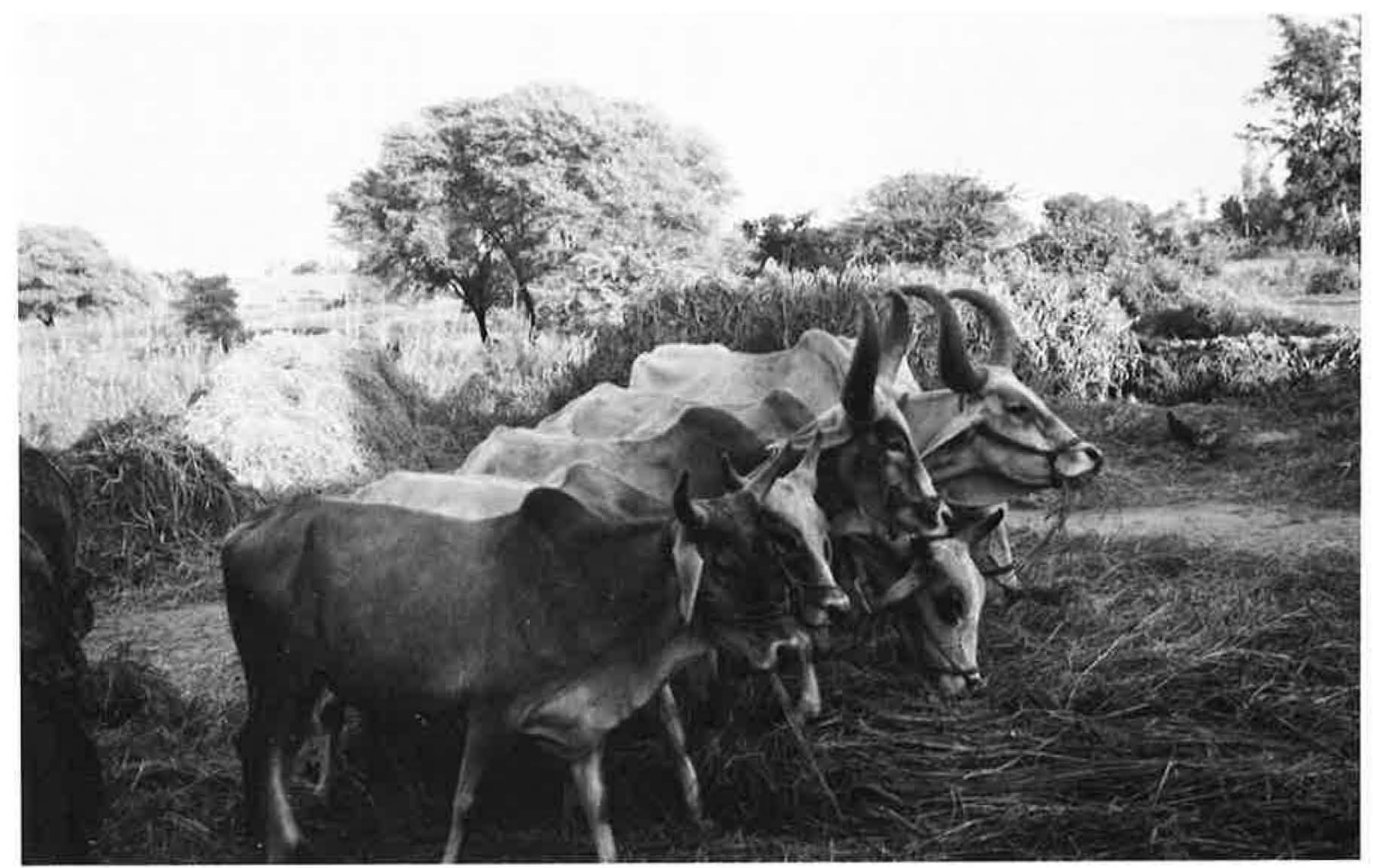

\section{SARTHI's Initial Work on Private Wastelands}

SARTHI's initial attempts to rehabilitate degraded lands began during the drought years of 1985 to 1987. Large numbers of cattle were dying due to the scarcity of fodder, and the remaining forests were being chopped down for firewood to earn income necessary for survival. Generating short-term wage employment by motivating landowners to plant fuel and fodder trees, therefore, seemed an appropriate intervention, as the immediate need for wages could be combined with a longer-term goal of increasing the productivity of degraded private lands.

With this objective in mind, SARTHI asked its field staff to identify interested small and marginal farmers who owned wastelands in their respective areas. There was no specific focus on involving women, although the female staff were asked to encourage women's participation. At this point, no local groups of either men or women had been formed and SARTHI staff were expected to rely on their contacts with local villagers that had been established through the organization's other ongoing projects.

After the planting season, review workshops were held with the staff in August and November 1988. They indicated that several sociopolitical problems had been encountered while implementing the new program. These included:
- Although landowners agreed to participate in the program, when earthwork started, many of them preferred to work on government drought relief programs instead of on their own lands. This was because SARTHI paid lower wages than the government programs and also because SARTHI insisted that the work be done according to specifications. As a consequence, SARTHI's field staff had to hire outside labor to work the landowners' land!

- Initially the landowners had specified a wide range of species they wanted to plant, but at the actual time of planting most demanded only eucalyptus even though it is believed to deplete the soil and subsoil water. One man even threatened to sue SARTHI for damaging his land unless eucalyptus was planted. (Eucalyptus is a fast growing tree used extensively in India for construction and for making paper. Until recently, it provided a good cash return although prices have since crashed due to over production.)

- Many landowners were hostile to the project due to a rumor that SARTHI would eventually take away both the land and the trees.

- Once the planting season was over, few landowners took an interest in protecting the plantings or completing the boundary trenches. 
It was clear that these landowners did not share SARTHI's interest in helping them develop their wastelands as a long-term asset. They seemed to equate this work with other government drought relief projects in which their only interest is in earning wages.

It was during these review workshops that staff learned of the work on four hectares of common land by one women's group in Muvasa, a village located about 10 kilometers from SARTHI's headquarters. This wasteland project had been started by SARTHI staff shortly after their return from the PEDO training program. Although some conflict with residents of an adjoining village who used to graze their cattle on that land was mentioned, the staff members faced fewer of the type of problems experienced with the landowners.

\section{The Shift to Working with Women's Groups}

It was the response of the Muvasa women's plantation group to a crisis in February 1989 that ended SARTHI's ambivalence about working with groups to develop common lands. Indeed from that time on all the field staff started organizing women's wasteland groups.

The incident that inspired this change was the following. The Muvasa group had harvested its first crop of grass from its four hectare planta- tion using voluntary labor. As the group had not yet decided what to do with the grass, it had all been left on the plantation itself.

One evening, while passing by, three drunken men from the adjoining village threw an unextinguished cigarette stub on the grass. All the grass went up in flames and the fire damaged many of the young plants carefully nurtured by the women.

Initially, the mishap sent a wave of despondency among the women's group and SARTHI. The plantation was the best out of the previous year's effort. But the women quickly gathered their wits and called a meeting to discuss what to do. Were they going to permit the three men to get away with such an act of irresponsibility? Did their labor have no value? If they did not punish the men, their future efforts could be similarly nullified. The group members and SARTHI staff discussed the incident with village leaders and a cross section of the population. They found that the majority were in favor of the culprits being punished. The women decided to demand compensation from the three men. The value of the damage was discussed and it was decided that the men should be made to pay 1,400 rupies (U.S. $\$ 78$ at the 1989 rate of exchange).

The men were summoned and told the group's verdict. Seeing the group's firmness and sensing that the entire village's sympathy was behind them, the men paid the Rs. 1,400.

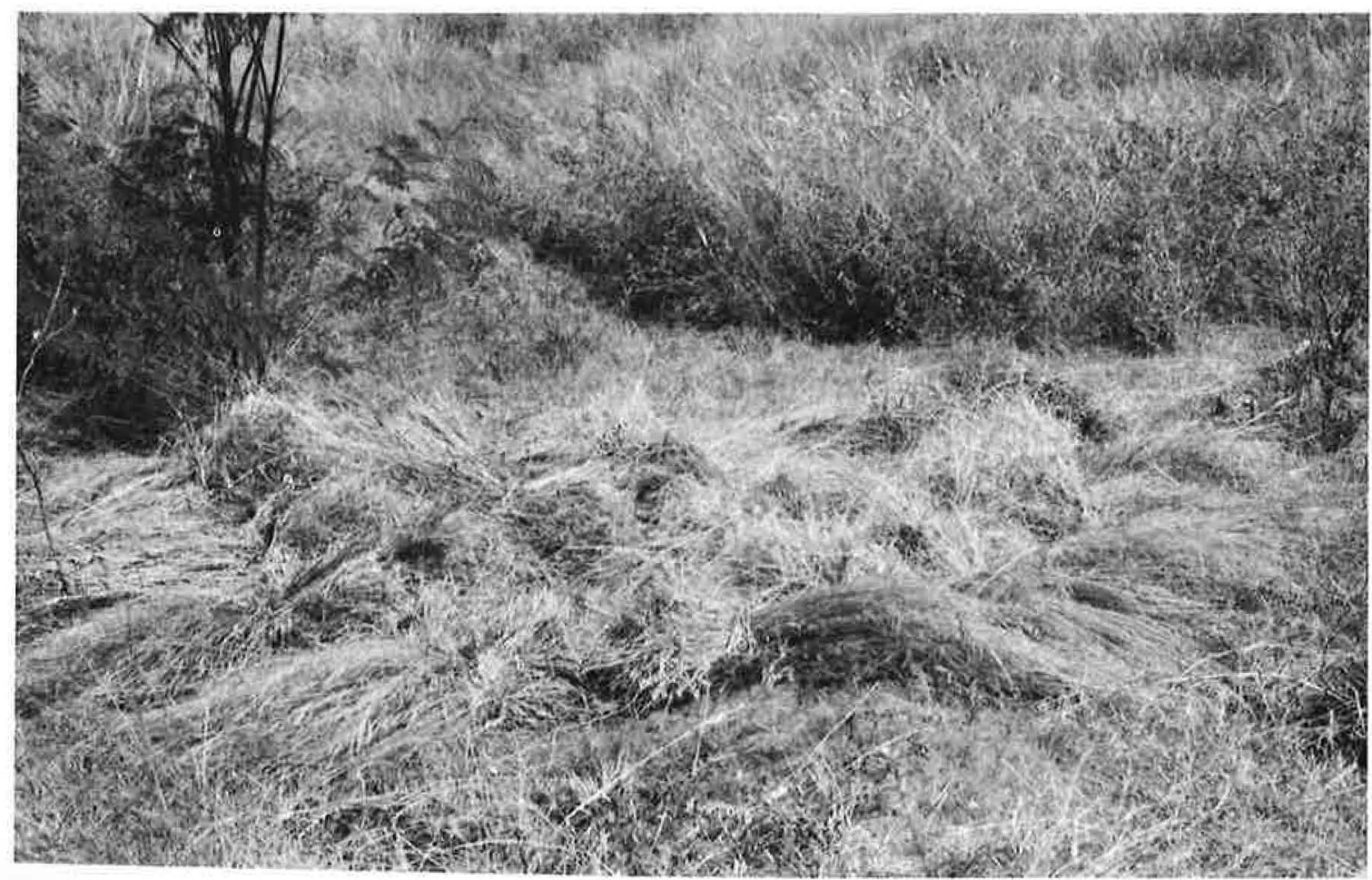




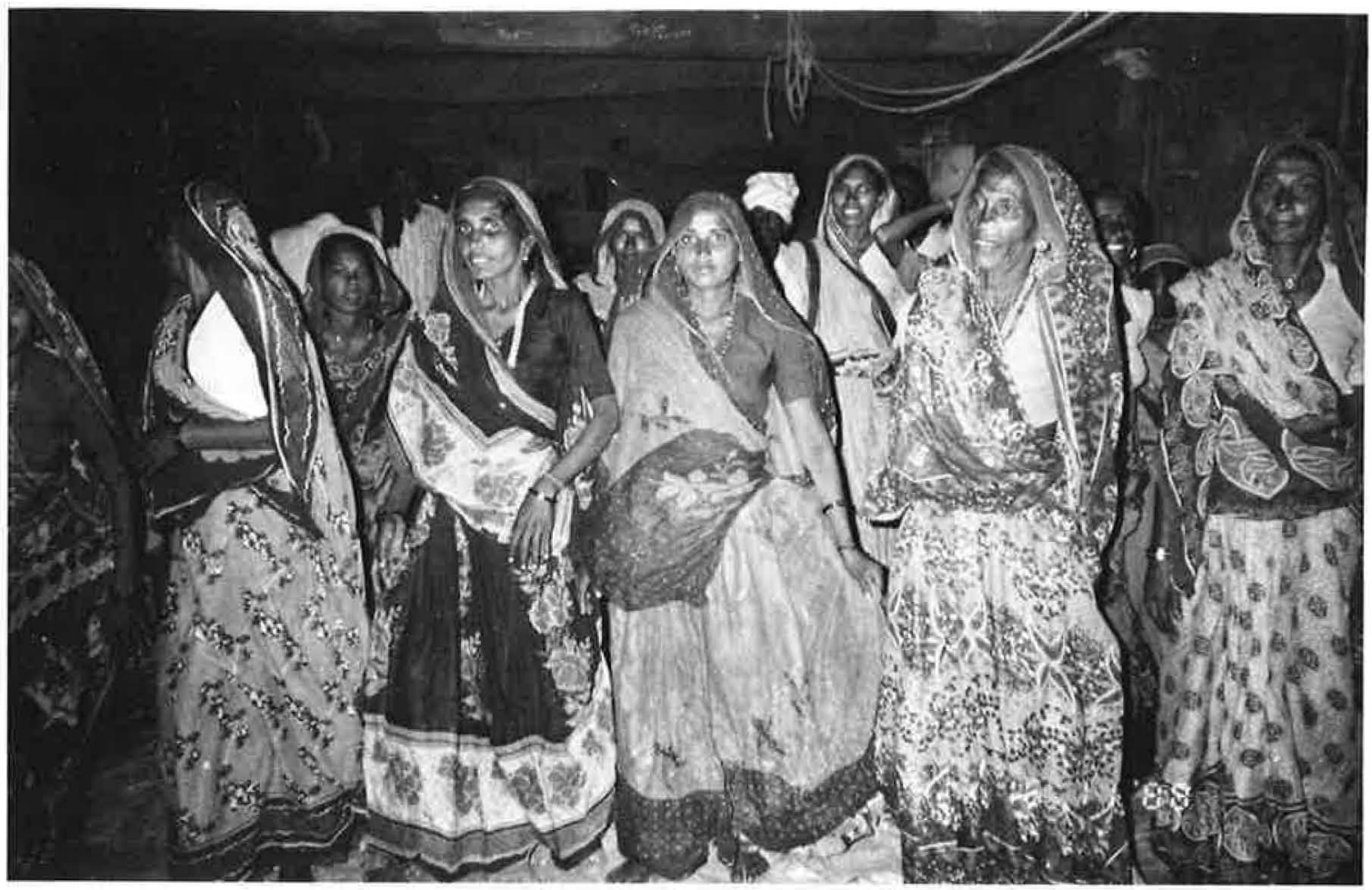

When the Muvasa field center staff narrated this incident during SARTHI's monthly staff meeting, the rest of the staff felt envious and inspired. The response of the women's group was worlds apart from the bickering, irresponsibility and manipulations of the private landowners. From then on, all the field staff strove to replicate the Muvasa group in their own areas.

\section{Formation of the Muvasa Women's Group}

It is useful to look at the process involved in the formation of the first group in Muvasa in order to understand the dynamics in operation in this and subsequent women's groups.

In early 1988, SARTHI had initiated private wasteland development with a few landowners in Muvasa. As many of these landowners did not work on their own land, SARTHI had to hire other laborers for this task. Most of these laborers were Adivasi women from the most disadvantaged families in the village. (In India it is very common for tribal women to work as manual laborers.)

As they went about their work, the women talked about their own hardships. They regretted their inability to participate in the program as their own landholdings were too small. Champa Ben and Vikram Bhai, SARTHI's field staff in Muvasa, took a lead from this and started exploring the possibility of the women's developing a piece of common land as a group. The women showed immense interest, and SARTHI was willing to pay for the land preparation and planting work. (Most Indian villages have at least some common grazing land to which all households have access. The management of this land is the responsibility of the panchayat. Many villages also have some revenue wastelands, i.e., land belonging to the revenue department, falling within the physical boundary of their panchayat. This is also effectively perceived of as common land even though the revenue department has the power to transfer it to individuals or groups.)

Impromptu meetings on the work sites resulted in some ground rules being worked out for the group. All those who became members would have to perform land preparation and planting work themselves. The group would accept collective responsibility for protecting the plantation. Each member would have a right to an equal share of the produce. All decisions related to the plantation would have to be taken collectively. Only women would be eligible for group membership, as it is they who suffer most due to fuel and fodder scarcity. All interested women in the village, including higher caste (Patel) women, would be invited to join. However, as the economically better off Patels do not allow their women to 

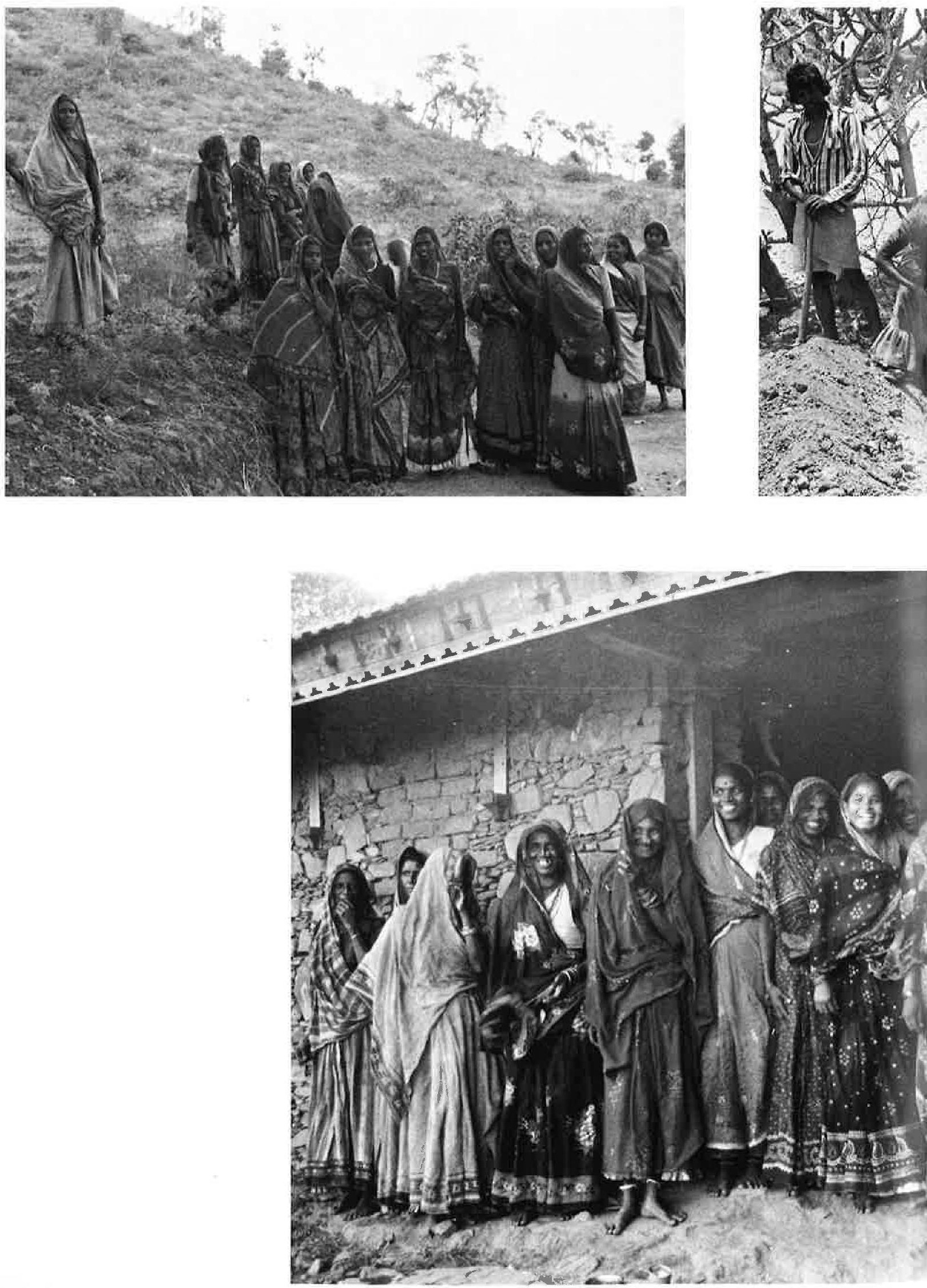

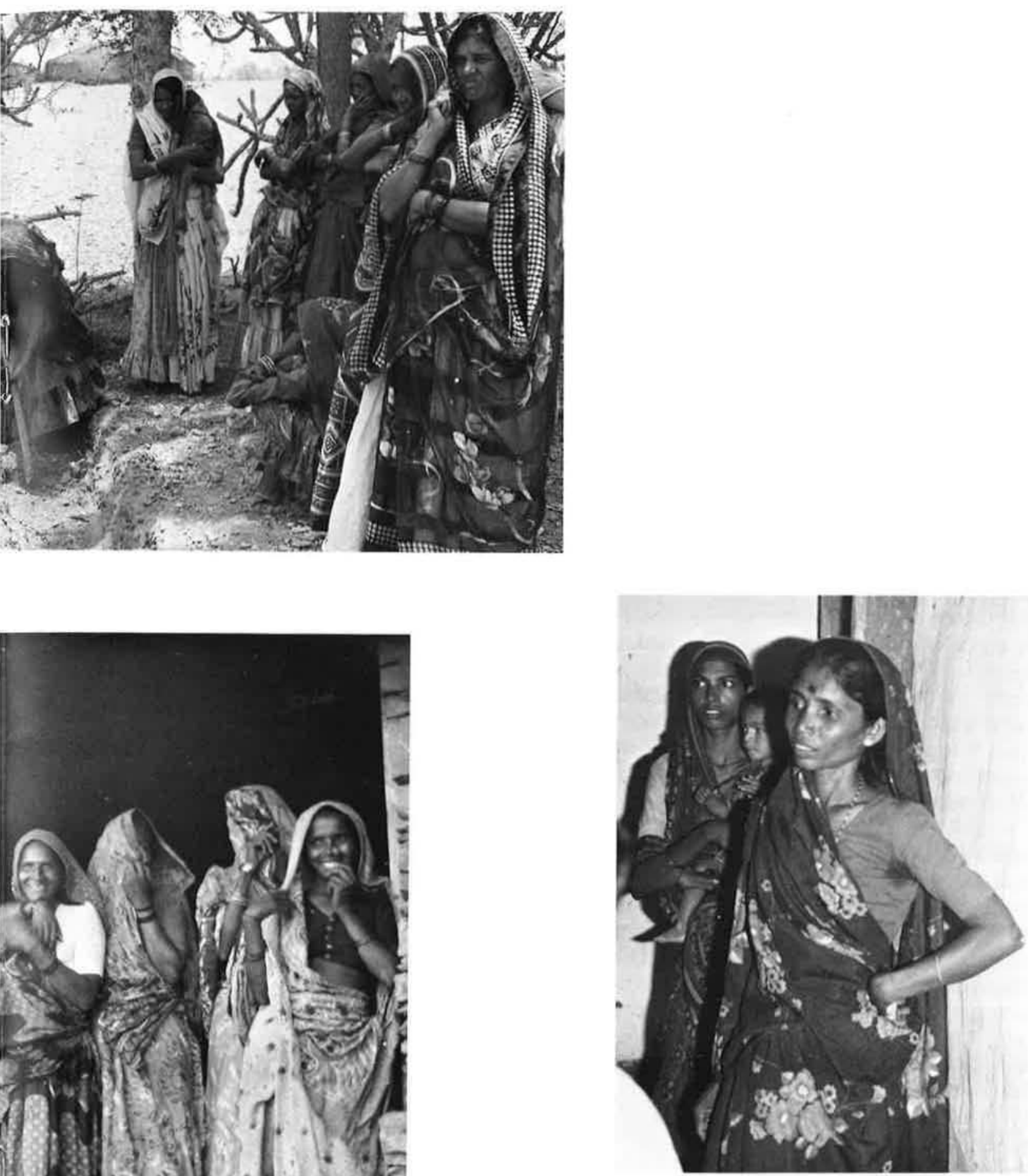
go out to work and because Pate/ women already have too much work to do on their families' larger landholdings, their membership was in effect ruled out.

With the group beginning to come together, the panchayat was approached. The panchayat gave a "no objection certificate" to the women, allowing them to plant four hectares of common land with a commitment to renew the lease after 10 years and making no claim to any share of the produce from the land.

Some of the more active women then went from house to house asking other non-Patel women whether they were interested in joining the group. A total of 29 women became members. They were all from the poorest families in the village, with some owning less than one acre of land. All were married but of different ages.

\section{Dealing with Men's Suspicions}

Even before the group started work on the land, village men started questioning why the organization was working only with women. The husbands of some members felt that housework was suffering and the time spent in meetings was wasted. At the family level, each woman had to use a combination of assertiveness and diplomacy. They started getting up earlier to finish their housework before going to work on the land or to attend meetings.

SARTHI's staff dealt with the men's suspicions by calling a meeting of the whole village to explain why they were working with a women's group. Women's increasing hardship due to scarcity of fuel and fodder and their having a greater stake in dealing with the problem were discussed. Although this and other discussions helped reduce suspicions, many men continued spreading rumors that SARTHI would abduct the women, take away their jewelry, etc. Some men would stealthily listen in on the group's discussions.

Slowly, however, as the group worked steadily and the women's self-confidence increased, the rumors and suspicions died down. SARTHI also helped by ensuring the participation of some local men in its other projects so that the men got better acquainted with the organization.

\section{Appropriating a Legitimate Social Space for Women}

Obtaining social consent for the women to organize themselves to deal with one of their major problems created, for the first time, a legitimate space for women to get together regularly. And for the first time, a group of village women obtained the right to manage a small part of village common land resources in accordance with their needs and priorities. Although none of the women individually owns any part of the land, they have gained acceptance of their right to manage it collectively. This in itself is a major breakthrough.

SARTHI's staff took care to ensure that representatives from each group participated in all negotiations with the male dominated panchayat and the revenue official (who maintains a record of land rights) to obtain the necessary documents for getting the land leased to the group. In the process, for the first time, the women got first-hand experience dealing with land-related matters. They began to see that their belief that only men have the competence to deal with such matters is a myth.

SARTHI's staff also ensured that the women themselves made all management decisions related to the plantation, to suit their situations and circumstances. For example, instead of the women being asked to work fixed hours, a system of flexible work hours was established. An account of the work done by each member was kept by the group and payment was made on the basis of output. This enabled the women to combine wage work on their plantation with their household work. Slowly, the women gained selfconfidence so that now they are able to demand that their husbands also help with household chores while they go to work, attend meetings or participate in training camps.

\section{Overview of SARTHI's Experience with Women's Groups}

At present, SARTHI is working with about 17 women's wasteland groups spread across all five of its field centers. In all cases the land is either panchayat gauchor (community grazing) land or revenue wastelands. Initiation of women's groups in other villages has taken different routes than in Muvasa. In some cases, SARTHI's field staff have first scouted around to find the necessary wasteland and have then tried to motivate local women to develop it as a group. In other cases, seeing the work of the Muvasa group, some male village leaders have approached SARTHI asking for a similar women's group to be formed in their village, offering the necessary wasteland. 


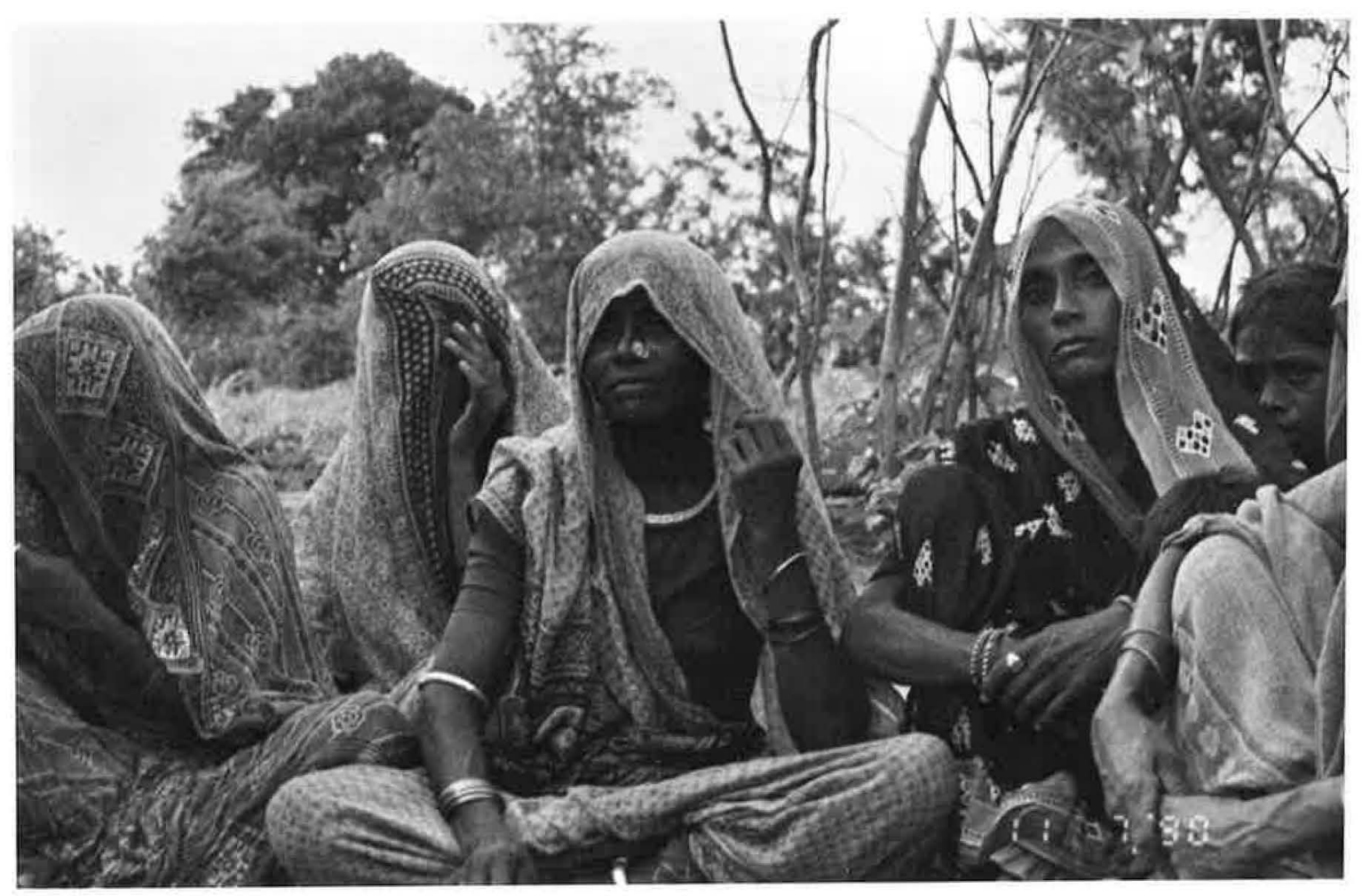

As may be expected, the experiences of the individual groups have varied. While some are developing well, others are still weak and some have fallen apart during the early stages of their formation. A complex range of factors influences each group's development. These include:

- power dynamics within the village and competing interests for use of common land;

- women's status and the extent of their exposure to the outside world;

- men's attitude towards women taking such initiatives;

- the skill, experience and leadership qualities of the field staff, particularly the women staff; and

- the extent of firewood and fodder scarcity in the area.

The most effective strategy for strengthening weaker groups has proved to be facilitating interaction between them and older, stronger groups.

\section{Sharing Experiences with Other Groups}

Each of the stronger groups has had to deal with a range of problems, but their determination and assertive methods for handling these obstacles have helped them consolidate and build group credibility. The need to take such action in the early stages of group formation has, in effect, minimized subsequent problems for these groups.

In addition to taking members of newly formed groups to visit older groups, SARTHI recently organized a two-day workshop in which representatives of several groups shared their experiences and problems. One of the major difficulties faced by many of the new groups is the attempt by manipulative village leaders to use the women to further their own interests. This was clearly the experience reported by the Paderi group during the recent workshop.

The Paderi women's group was formed in 1990, and SARTHI helped it plant a variety of species on a piece of degraded wasteland. In the beginning, the group seemed to be working well and appeared united. During group meetings, village men maintained a safe distance from the venue of the meeting lest the women ask the men to serve water to the women, a role traditionally played by women! However, over time group unity began to break down and the plantation was no longer being protected from grazing animals.

The four members of the group attending the workshop claimed that one drunken man refused to cooperate with protection of the plantation and had threatened violence against anyone 
attempting to stop him. The women had come to the workshop to demand, on behalf of the group, that SARTHI pay for a full-time watchman to protect their plantation. Despite being told that, as a matter of principle, SARTHI does not pay for watchmen as protection can effectively be done only by the groups themselves, the women remained adamant about their demand.

Informal discussions with the local field staff subsequently revealed that the husbands of two of the group members were currently running for election as the village sarpanch (head of the elected Panchayat). Both were trying to use their wives to extract a benefit from SARTHI that would strengthen their own position within the village. The women had fallen prey to this manipulation with the result that the group had split into two opposing factions.

Representatives of other groups present were asked whether they had faced similar problems and how they would deal with the situation the Paderi group was facing.

Karsan Ben of the Wankdi group said that some months ago, four or five goats belonging to their village sarpanch were caught grazing inside the group's plantation. Eighteen women got together, caught the animals immediately and had them locked up in the cattle pond (yard) maintained by the panchayat. Interestingly, this area is looked after by the sarpanch himself. He was not allowed to release his own goats until he had paid a fine of Rs.700 to the group! With not even the sarpanch having been spared by the women, others got the message loud and clear. There were no further incidents of grazing in their plantation.

Earlier, when the Wankdi group began planting on its land, the members decided to allow male family members to work on the plantation. However, the men's performance proved unsatisfactory. For example, it was found that while carrying plants uphill from the nursery, the men had been dropping some on the way to reduce their load. This resulted in fewer plants being planted than were taken from the nursery. The group therefore forbade the men, including members' husbands, from working on their plantation in the future!

Similarly, the group has learned to be firm about not permitting any men to sit in and listen while they are having their meetings. As women in the area practice purdah (covering their heads and faces) in the presence of older male relatives, they cannot talk openly in front of men and this defeats the purpose of the women meeting separately. The extent to which the women have succeeded in making group meetings a "women only" space is evident from a remark overheard from some village men. They were telling each other to stay away from the women's meeting lest the women start demanding a right to attend exclusive men's meetings!

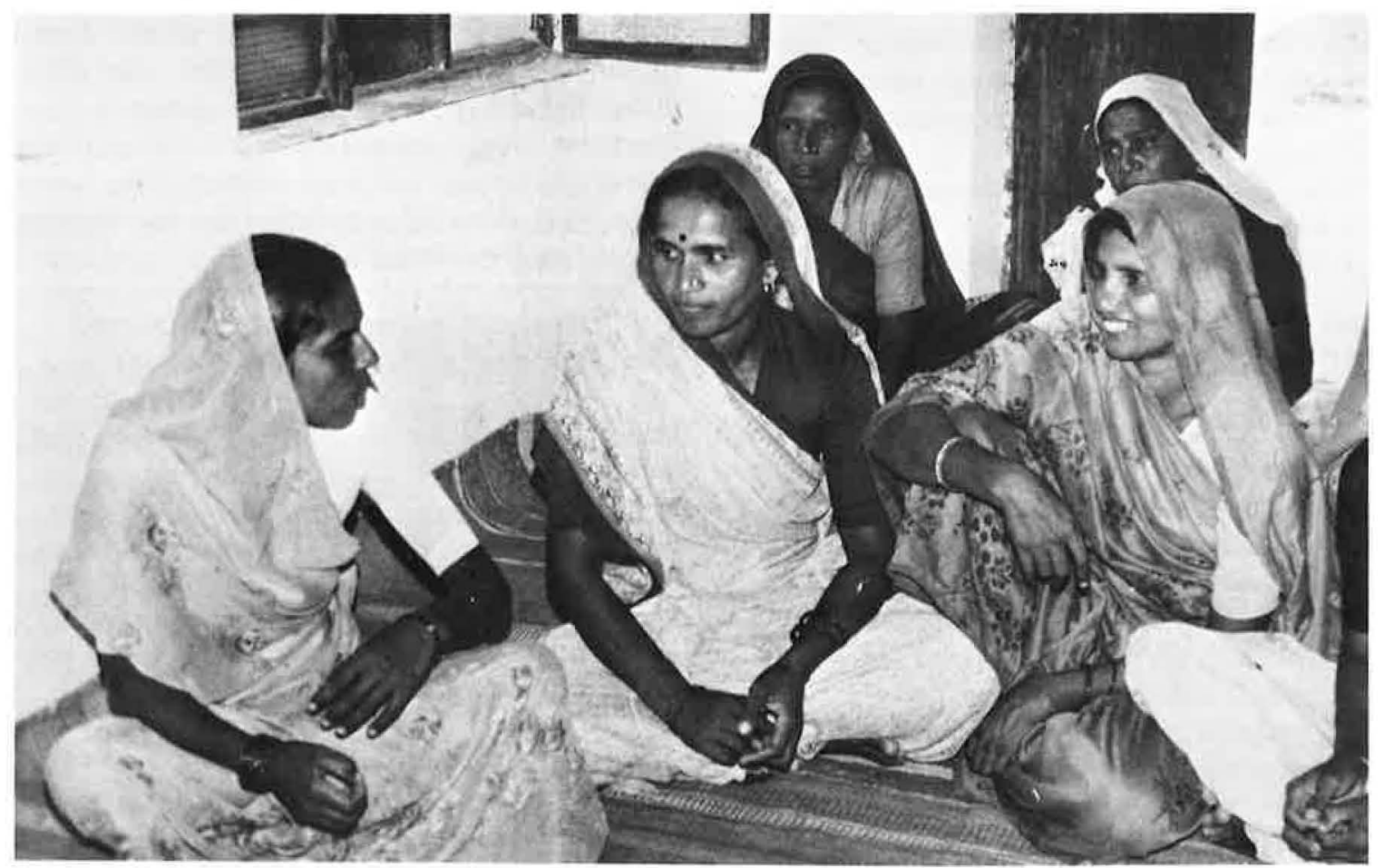




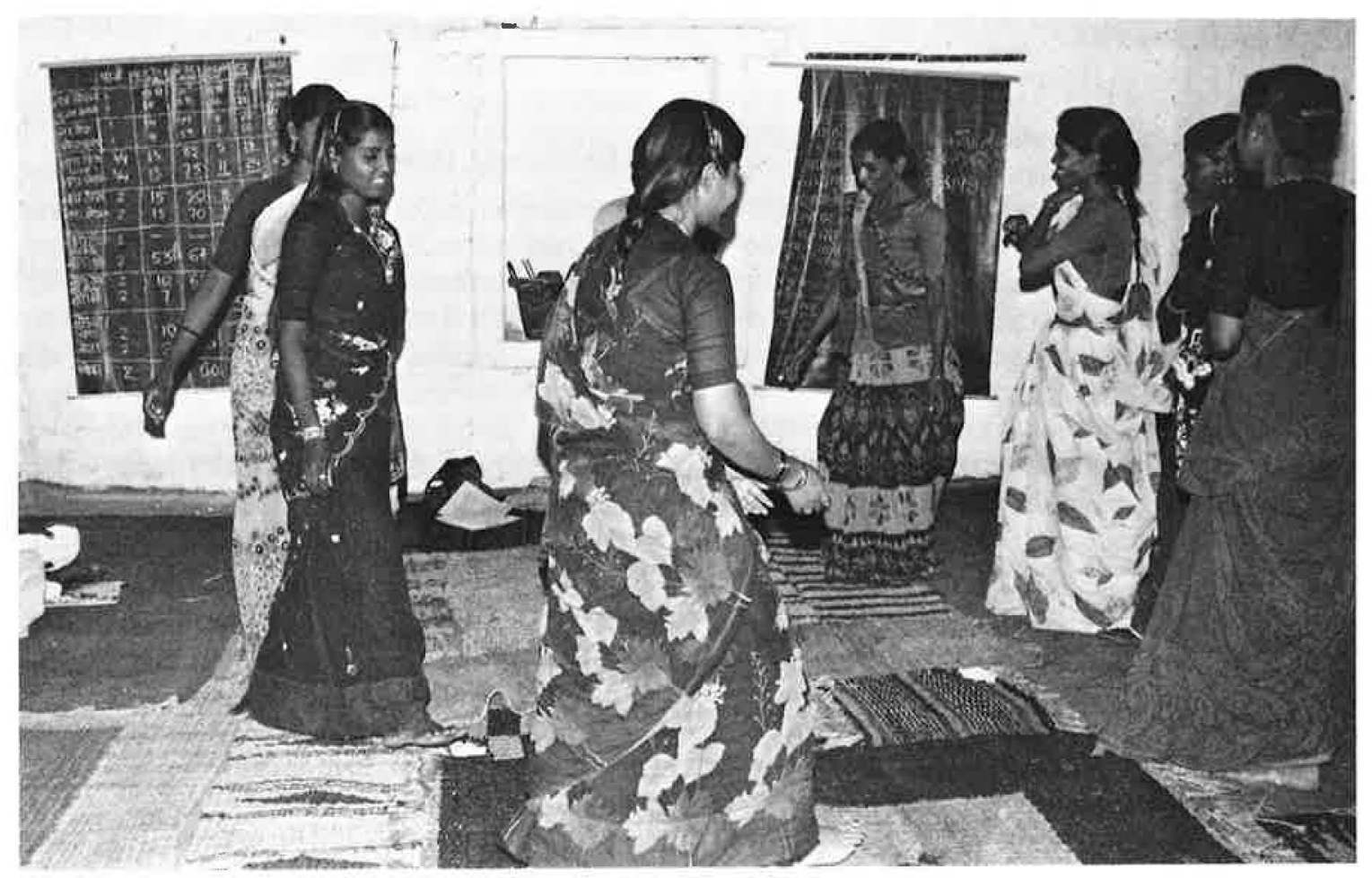

During the workshop, Kapuri Ben of the Wandariya group narrated her group's experience in the early days. After completing work on their land, the women had planted Ipomea (a nonbrowsable shrub) as live fencing all around it. One man living near the plantation uprooted the lpomea fencing as he wanted to continue grazing his cattle on the land. With SARTHI's help, the group registered a complaint with the police and the man had to pay a hefty fine. He never tried letting his cattle into the plantation again. However, to compensate him for the loss of the grazing facility and to avoid alienating him from supporting their objectives, the group engaged him as their watchman.

Kapuri Ben asserted that there was no problem with any men trying to physically beat any of their group's members. If anyone tried any such thing, the women would beat the men back!

Nani Ben of the Muvasa group said that if the Paderi group were united, no drunkard would dare threaten group members or graze his cattle on their plantation. She narrated a recent situation faced by her group. As the group's plantation is located some distance from where the women live, one man living near the land had been letting his cattle into their plantation at night. He was even cutting their grass on the sly. The women decided to catch the man red handed.

One day, 15 group members hid themselves inside the plantation. When the man sneaked in with his cattle, all the women jumped up and confronted him. The man started verbally abusing the women, saying they could not stop him. At this point, Kanta Ben, one of the group members, grabbed him by the neck of his shirt and demanded that he apologize for being abusive. Frightened out of his wits, the man repented. Since then, he has never interfered with the plantation.

Members of the Gara group asked what was the use of forming a group if so many women were still going to allow one drunkard to intimidate them. The only solution lay in collective action.

The Paderi women got the clear message that the solution to their problem did not lie in pestering SARTHI to pay for a watchman to protect their plantation. They promised to go back and try to pull their group together. 


\section{Returns from the Groups' Plantations}

The older groups have started getting some returns in the form of biomass (fodder grass, seeds, some legumes and small amounts of firewood) from their plantations and are in the process of refining their harvesting and distribution systems. The Muvasa group has harvested grass three times. The first crop got burned but during the second year the women took half the grass they cut for their own use and sold the other half. The third year, the women took equal amounts home to feed their cattle.

The Wandariya and Wandki groups have not been able to harvest much grass yet as their land is rather stony. However, the Wandariya group has already produced some tree leaf fodder and firewood from their efforts at regenerating existing trees. This is done by cutting the multiple shoots from existing root stock to allow only one healthy shoot to grow. The cuttings are used as firewood.

The Gara group is planning to allow its members to cut green grass this year as it is a more nutritious fodder. Each member will be asked to pay a small amount for the grass in order to build up the group's common fund.

By planting seeds of an improved fodder grass variety, the poor quality local grass is slowly being replaced by a much more nutritious grass on all the plantations. The groups have also started collecting grass seeds to supply to SARTHI for use in new plantations.

\section{Additional Benefits}

Besides providing a source of biomass under the women's own control, participation in group activities are leading to other improvements in the women's lives. For example, follow-up visits by WHWs revealed acute nutritional deficiencies (particularly of vitamin A, which leads to night blindness in children and pregnant women) among villagers. Discussions about dietary patterns and nutritional beliefs and practices revealed that the limited variety of foods being eaten resulted in insufficient consumption of protective foods such as milk, milk products, leafy vegetables, fruits and, to some extent, legumes. Milk products and fruits are not readily available in the area and, during the dry summer months, neither are green leafy vegetables. Even when such foods are available, women often lack the time to prepare them due to their excessive work burdens.

These discussions in turn led to the integration of nutritionally important trees in SARTHI's wasteland program. These include aonla (phyllanthus emblica), a local species whose fruit is one of the richest known natural sources of vitamin $C_{\text {, }}$ and sengwa (moringa oleifera), the leaves of which are rich in vitamins $A$ and $C$. These leaves

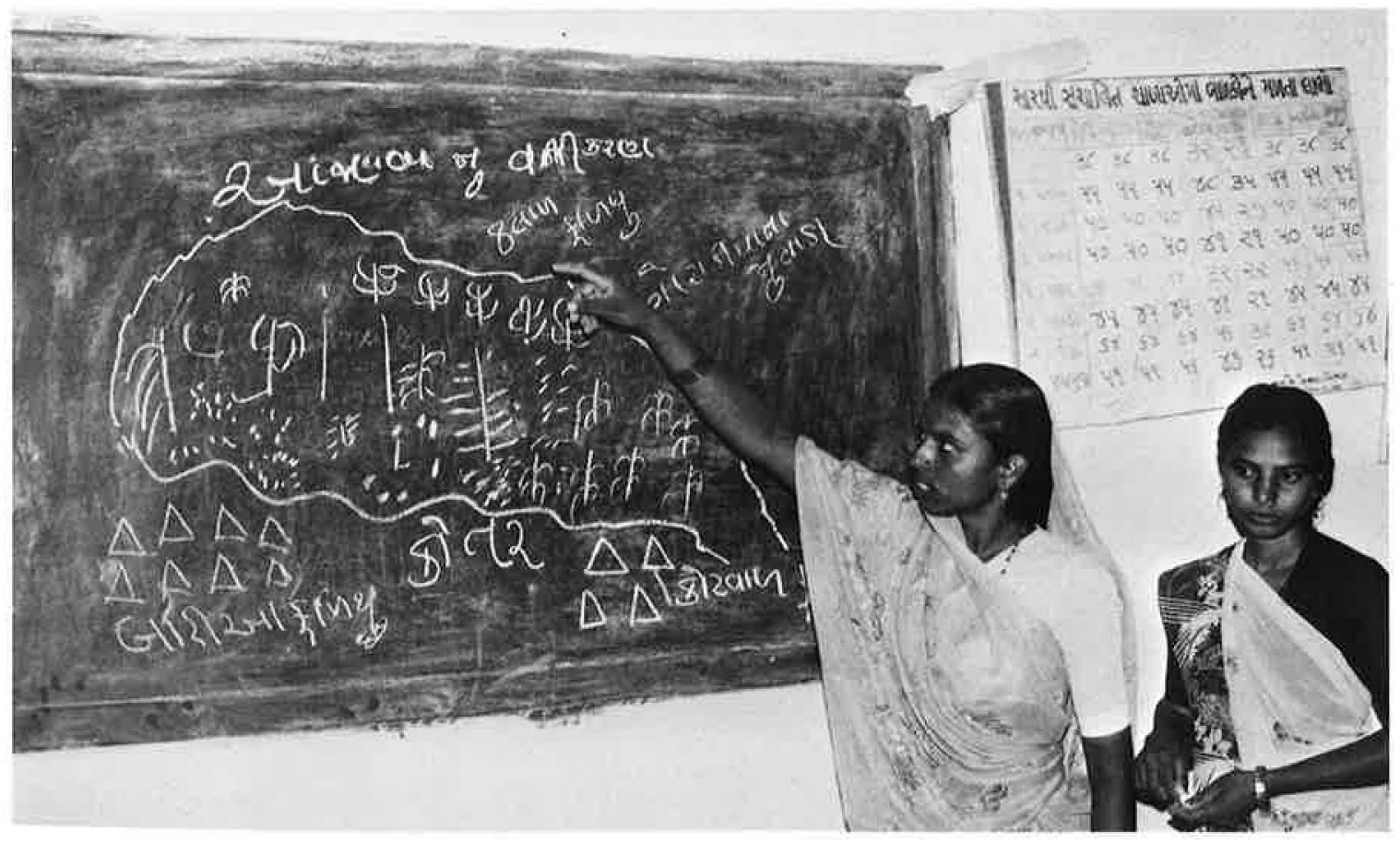


can be lightly cooked and served as spinach during the summer months when no other leafy vegetables are available.

During 1989, a resource team began collecting folk knowledge about local trees and shrubs to aid in species selection for the wasteland program. It became evident from the dais that there was a rich local tradition of using medicinal herbs and plants for women's health problems. The local forests yield many medicinal herbs and plants, so integration of species of medicinal value became a new facet of the wasteland program.

During 1989-90, as a result of the women's wasteland groups, women of different villages formed about 20 women's savings groups. These groups emerged out of the strongly felt need of the women to create their own source of credit for emergency loans, thus removing the need to rely upon exploitative local money lenders.

Intergroup meetings have become the forum for all three cadres of SARTHI's trained women field staff to interact with village women and increase their awareness and knowledge about various problems. In addition, several awareness generating and leadership development camps have been organized for selected village women at SARTHI's headquarters and camps on clean drinking water and the environment have been held in several villages. Many women have been sent to melas, workshops and camps $^{2}$ organized by other organizations on themes relevant to women's lives. Visits between members of different local groups have also been organized.

Each opportunity for a village woman to step outside the village and interact with large numbers of other women is in itself a very empowering experience. Traditionally women have few opportunities to interact with women outside their family and community networks. Even within the community, the only time women get together are for events such as marriage, death or religious ceremonies where they are expected to perform their traditional roles. Through the SARTHI program, women are able to share experiences with women from diverse castes and communities. Besides acquiring new knowledge, they are able to shed

\footnotetext{
${ }^{2}$ Camps are normally one to five-day events during which a selected group or village is provided with information on one or more selected topics. Melas are similar to camps but tend to be larger. Both melas and camps may be residential, requiling participants to stay away from home. Participants' travel and other costs are normally paid for by government or NGO sources.
}

some of their traditional sharam ${ }^{3}$, shyness and inhibitions.

Today, SARTHI's women's activities are becoming the organization's major program. Due to women's positive response to each awarenessraising effort, SARTHI has essentially switched from individual beneficiary oriented projects to programs geared toward organizing and mobilizing women and youth, as well as men. Because the internal hierarchy of families and communities can severely restrict empowerment, most frequently by gender or age, use of the group dynamic can be an effective means to break down such barriers to participation by women and other nondominant groups.

\section{Future Directions}

Although all the groups will soon start harvesting some biomass from their plantations, a major problem they face is that, in most cases, their plantation areas are too small to meet all their needs and additional village common lands are simply not available nearby. If the women's groups were to try to enclose more of the limited amount of available grazing land, they would face the danger of getting into conflict with families dependent on use of those lands to graze their cattle.

However, having entered the field of natural resource management, the women are now looking at how other public lands in the area are managed. The largest category of public land with tremendous potential for increased productivity is forest land now held by the state forest department. Fortunately, the Gujarat forest department realizes that it cannot improve management of its forest lands without the cooperation of villagers living in the vicinity. The department is, therefore, in the process of introducing a joint approach to management of forest land and SARTHI has begun exploring the possibility of the women's groups participating in this program.

The task of legally securing the women's groups' tenurial rights to the common lands remains to be completed. All the groups have obtained "no objection certificates" (NOCs) and supportive resolutions from their panchayats to work the land and enjoy its produce for a number of years. But the legal validity of these NOCs and

\footnotetext{
3There is no adequate translation for the Indian term sharam, which includes an acute sense of shame and embarrassment over having to act or behave outside one's traditional role. It is this sense of sharam, more than anything else, that keeps Indian women so strongly bound to tradition.
} 
resolutions remains ambiguous. One concern is whether a newly elected panchayat can overrule or withdraw a NOC given by the previous government.

Such legal ambiguities can be compensated for to a considerable extent by the empowerment of the women; the newly elected panchayat would not have the courage to withdraw the land for fear of the repercussions. However, this can only be done by broadening the base of support for the women's groups among different sections of the community and by strengthening the women's political voice within local institutions. Most of the groups have achieved remarkable success thus far in demanding supportive action from panchayat members during every crisis or conflict on the grounds that it is the panchayat's responsibility to get the terms of their NOCs honored.

The potential of recurring conflicts over scarce common land resources from competing interest groups will remain high. The women's resolve to assert their rights will be put to the test repeatedly over time. For example, the Muvasa group is now having to fight yet another major battle. Apparently six families from an adjoining village recently chopped down and stole most of the trees from their plantation. The group registered a complaint with the police and demanded action from the panchayats of both villages against the culprits. For the first time, the panchayats of two villages have been involved, resulting in inter-village tensions. SARTHI helped the women organize a rally that took the group's case to adjoining villages to broaden their base of support. However, information about the final outcome of the Muvasa group's latest struggle is not yet available. But given the determination they have displayed thus far, they are sure to fight on. And a long fight it is sure to be.

\section{Lessons Learned}

As primary gatherers and users of biomass, women are in the best position to implement wasteland development activities, as they possess both the knowledge and motivation to successfully carry out such programs. However, as women in a male-dominated society, they require assistance in overcoming a range of obstacles that have traditionally hindered them from working together, taking action and asserting their influence within the community. SARTHI's experience of organizing women around the development of wastelands yields important lessons in terms of both the management of natural resources and the empowerment of women.

1. Bringing women together in groups provides them with the power they need to break the confines of the family and community norms. Women's collective needs cannot be met unless the gender division of labor at home and in the wider society is challenged. Women's participation in the wasteland groups has allowed them to challenge the hierarchy of the family as evidenced by some husbands taking on household chores to enable their wives to attend group meetings or to participate in training camps. Women's new selfesteem is also visible as wives begin to drop some of their traditional subservience to husbands on the strength of having to honor decisions taken by their group. Finally, individual group members have been able to bring an end to physical abuse and violence in their homes due to the support of their group.

2. Among the strengths of the women's wasteland groups are the standards of democratic participation and fairness with which they operate. Decisions about hours, output and quality of work are all made democratically and all participants share equitably in both the labor and resulting product. This model contrasts markedly with patterns found in male-dominated social, political and governmental institutions that increasingly serve the needs of special interests, as was exemplified by the behavior of the private landowners with whom SARTHI originally worked.

3. By defining conditions of eligibility to join the first women's wasteland group at the outset, the Muvasa group created realistic expectations about members' rights and responsibilities. As an explicit condition of participation, all members had to work on the land themselves to be entitled to an equal share of the produce. This strategy naturally excluded higher caste women from membership based on their work status rather than because they were not asked. At the same time, the process assured that there would be coherence among the group in that all the members shared a similar background.

4. Trained field staff are needed to facilitate creation of a women's space within the community. This is a minimum condition necessary to organize women, particularly where there are no traditional opportunities for them to get together outside the confines of the family. Lack of public and social space for women is an obstacle to their asserting their rights. When such a space is created, it provides women with a new resource and 
implicit acknowledgment of their rights by the community.

5. Women's sense of collective power is enhanced by creating opportunities for women to move about not only outside their homes, but beyond their communities as well. Geographic mobility is not only symbolic but also provides practical opportunities for women of different backgrounds to receive training, learn new skills and gain an understanding of the structure and functioning of government institutions. Attendance at "outside" meetings can foster women's self-confidence to speak out in larger gatherings and to assume leadership roles.

6. Sensitizing field staff to gender issues and encouraging them to explore locally appropriate strategies for empowering women can be a more effective approach to the development of successful projects than simply imposing a predetermined program. Thus the organic process by which the women's wasteland groups have developed has now become a model for the broader range of SARTHI's development work.

7. The women's wasteland groups were able to validate and "mainstream" their gains by insisting that their respective panchayats uphold their land rights when challenged both from within and outside of their communities. By holding the panchayats accountable for enforcing NOCs (no objection certificates) given by them, the women established their equal standing as citizens of the community. Had they selected a less public strat- egy, they might have marginalized their standing. This action is also likely to result in the women using their right to vote in panchayat and state elections in the future to promote their interests, thereby increasing women's participation in political processes and institutions.

8. The women's groups evolved by both rewarding productivity and by challenging directly and immediately all efforts to trivialize or exploit their work. They successfully demanded recompense for damage to their plantations, punished or directly confronted all attempts to intrude upon or distract time and resources from their work. The immediacy and intensity of their responses undoubtedly were important to their being taken seriously by both other women and men in their communities.

9. The short-term and practical gains the women have made can be complemented by changes planned strategically across generations. On the short-term level, the wasteland projects offer an opportunity for adult women to gain collective tenurial rights over at least communityheld land resources. This can be viewed as a first step in the assertion of women's rights to own private land in their own name-something that is highly uncommon in India. Some group members have already articulated the hope that their daughters will at least have an equal opportunity to share in their parents' property. Only through such strategic thinking will gender relations begin to change in the long term.

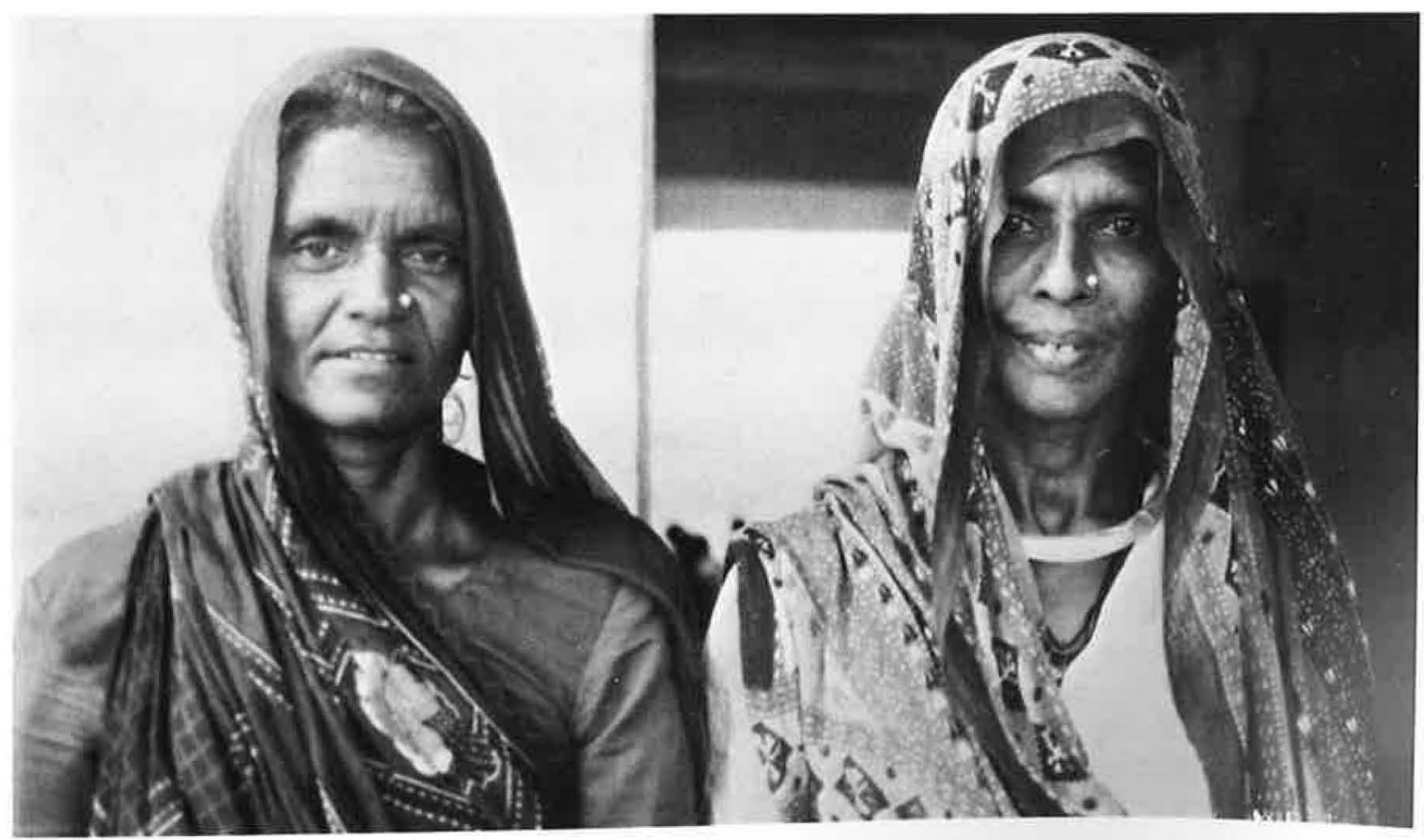




\section{Appendix}

Listed below are a few publications that deal with issues related to the environment and women's empowerment. Please contact publishers directly to determine availability, costs and applicable handling charges.

Asia \& Pacific Women's Resource and Action Series: Environment, (APDC, P.O. Box 12224, 50770 Kuala Lumpur, Malaysia, 1992)

Cold Hearths and Barren Slopes, the Wood Fuel Crisis in the Third World, by Bina Agarwal (ZED Books, 57 Caledonian Road, London N1 9BU, England, 1988)

"Community Management of Waste Recycling: The SIRDO," by Marianne Schmink, available in English \& Spanish (SEEDS, P.O. Box 3923, Grand Central Station, New York, NY 10163, USA, 1984)

"Forest Conservation in Nepal: Encouraging Women's Participation," by Augusta Molnar, available in English, Spanish and French (SEEDS, P.O. Box 3923, Grand Central Station, New York, NY 10163, USA, 1987)

"Gender Planning in the Third World: Meeting Practical and Strategic Gender Needs," by Caroline O.N. Moser (World Development, vol. 17, no. 11, 1989)

Women and the Environment: A Reader, Sally Sontheimer, ed. (Monthly Review Foundation, 122 West 27th. St., New York, NY 10001, USA, 1991)

The Bankurra Story: Rural Women Organise for Change and Technical Cooperation report, by Nalini Singh (ILO, World Employment Branch, New Delhi, India, 1988)

"Women, Environment and Development," The Tribune, Newsletter 47, September 1991 (IWTC, 777 United Nations Plaza, New York, NY 10017, USA)

Madhu Sarin, initially individually and later as a member of a small team of women resource persons, has been professionally associated with both SARTHI and PEDO since 1983. She would like to express her gratitude to:

- the members of all the women's groups for giving so much of their time and for sharing the exciting process of change they are experiencing;

- the director and all the field staff of SARTHI for sharing their insights and knowledge; and

- her dear friends and colleagues, Renu Khanna and Chandrika Sharma, with whom she has worked and learned together since they began their explorations into changing rural women's roles in the management of local resources. 
Design: Ann Leonard

Photos: Madhu Sarin

Typography: Village Type \& Graphics

Printing: Graphic Impressions

\title{
Other Editions of SEEDS Currently Available
}

No. 2 Hanover Street: An Experiment to Train Women in Welding and Carpentry-Jamaica (English, Spanish)

No. 3 Market Women's Cooperatives: Giving Women Credit-Nicaragua (Spanish)

No. 4 Women and Handicrafts: Myth and Reality-International (English, Spanish, French)

No. 5 The Markala Cooperative: A New Approach to Traditional Economic Roles-Mali (English, French)

No. 6 The Working Women's Forum: Organizing for Credit and

No. $7 \mathrm{De}$ Chanoe-India (English, French)

No. $8 \mathrm{C}$

C

No. $9 \pi$

No. 10

HQ Sarin, Madhu.

No. 11

1870.9

Wasteland

.S43 development and the

No. 12

no. 16

empowerment of

No. 13

women

No. 14

No. 15

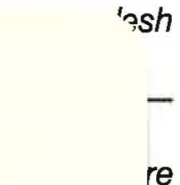

GAYLORD $S$

If you would like additional copies of this issue or any of the editions of SEEDS listed above, please write to us at the address given below. Copies of selected SEEDS issues in local languages are currently being published by organizations in the following countries: Egypt, India, Indonesia, Kenya, Nepal, Pakistan, Thailand and Vietnam. Please write to us for more information if you are interested in these materials.

\author{
Ann Leonard, Editor \\ SEEDS \\ P.O. Box 3923
}

Grand Central Station

New York, New York 10163, U.S.A. 


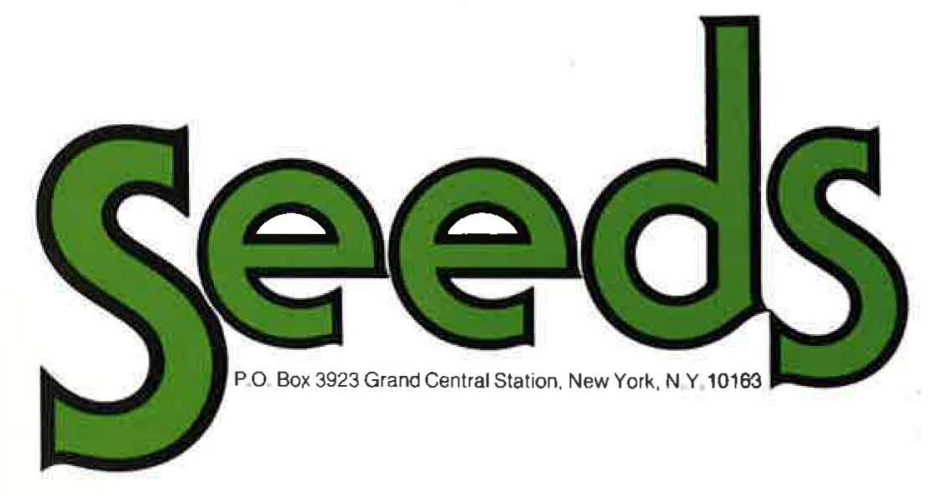

